Robert Pietrygała

Uniwersytet Wrocławski

iD ORCID ID: 0000-0002-7093-8219

Zdzisław Cutter

Uniwersytet Humanistyczno-Przyrodniczy

im. Jana Długosza w Częstochowie
OBLICZA WOJNY

TOM $1 \cdot$ ARMIA KONTRA NATURA

ŁóDŹ 2020 • ISBN 978-83-8220-055-3 • s. 275-287

http://dx.doi.org/10.18778/8220-055-3.17

iD ORCID ID: 0000-0003-0520-0397

\title{
AMERYKAŃSKIE WOJSKA INŻYNIERYJNE W KONFLIKCIE WIETNAMSKIM 1964-1975
}

W ojna wietnamska była jednym z najdłuższych i najkrwawszych konfliktów po II wojnie światowej. Można ją podzielić według najnowszej periodyzacji dziejów Wietnamu na dwa okresy: I wojnę indochińską (1946-1954) i II wojnę indochińską (1957-1975).

Wietnam stanowił największe państwo tzw. Indochin francuskich ${ }^{1}$. Ukształtowało ono swoją historię², tradycję i kulturę z krzyżujących się tam wpływów dwóch wielkich cywilizacji: chińskiej i hinduskiej. Wietnam liczył blisko $60 \mathrm{mln}$ mieszkańców, zamieszkałych na obszarze około 330 tys. $\mathrm{km}^{2}$ i dominował swoim potencjałem, zarówno ludnościowym, jak i gospodarczym, nad pozostałymi państwami Indochin ${ }^{3}$.

Zanim w konflikt zaangażowały się Stany Zjednoczone, Wietnam był przez blisko 90 lat pod panowaniem Francuzów, którzy w 1858 r. - pod pretekstem ochrony misji katolickiej - zajęli południową część kraju (w wyniku ciągłych powstań i buntów miejscowej ludności Francuzom udało się zająć cały kraj dopiero w 1883 r., kiedy to opanowali siedzibę cesarzy Wietnamu - Hue ${ }^{4}$ ). Pierwszym poważnym bodźcem do zrzucenia francuskiej dominacji było utworzenie

${ }^{1}$ Terminem tym powszechnie określa się trzy państwa stanowiące kiedyś posiadłości francuskie na Półwyspie Indochińskim: Laos, Kambodżę i Wietnam.

${ }^{2}$ Historia Wietnamu liczy 2 tys. lat (utworzony w 207 r. p.n.e przez jednego z wodzów chińskich - Trieu Da Sino), z czego 10 wieków pod panowaniem Chin.

${ }^{3}$ P. Ostaszewski, Wietnam, najdłuższy konflikt powojennego świata 1945-1975, Warszawa 2000, s. 27.

4 A. Dмосноwsкi, Wietnam 1962-1975, Warszawa 2004, s. 7. 
Wietnamskiej Partii Narodowej (Quoc Dan Dang - VNQDD). Zainicjowane przez nią powstanie zostało jednak stłumione, zaś większość działaczy wyemigrowała do Chin. Powstanie to nie pozostało bez echa, gdyż stało się impulsem dla działaczy komunistycznych do powołania Indochińskiej Partii Komunistycznej, na czele której stanął - jak się później okazało - bohater narodowy Wietnamu, Nguyen That Hann, znany jako Ho Chi Minh. Pseudonim, który przybrał - „Ten, który wynosi światło” nie był przypadkowy, wskazał i „oświetlił” bowiem Wietnamczykom drogę do niepodległości. Ostatecznie kres panowaniu francuskiemu w Wietnamie położyła klęska wojsk francuskich pod Dien Bien Phu, które skapitulowały - po 55 dniach walki - 7 maja 1954 r. ${ }^{6}$ Tym samym tzw. I wojna indochińska dobiegła końca.

Po zakończeniu tej wojny - o przyszłości Wietnamu zadecydowała konferencja w Genewie 7 . Jednak podpisane wówczas umowy miały niewielkie szanse na wcielenie ich w życie, gdyż USA nie mogły się zgodzić na zjednoczenie kraju pod przywództwem komunistów z Viet Minhu. Wynikało to z ówczesnej polityki Białego Domu opartej na tzw. teorii domina, nakreślonej jeszcze w kwietniu 1954 r. przez ówczesnego prezydenta Stanów Zjednoczonych - Dwighta Eisenhowera, który powiedział: „Mamy rząd kostek domina, przewróćmy pierwszą i to samo stanie się bardzo szybko z ostatnią. Strata Indochin z całą pewnością pociągnie za sobą upadek Birmy, Tajlandii, i Indonezji"8.

W 1960 r. z inicjatywy Wietnamskiej Partii Pracujących powstał Narodowy Front Wyzwolenia Wietnamu Południowego. Był to klasyczny „front ludowy” stworzony na wzór wcześniejszego Viet Minhu - członków tego Frontu zaczęto nazywać Vietcongiem ${ }^{9}$. Rok wcześniej - 8 lipca 1959 r. partyzanci z północnego Wietnamu po raz pierwszy zaatakowali bazę armii południowowietnamskiej w Bien Hoa. Nie byłoby w tym nic dziwnego, gdyby nie fakt, że podczas tego

${ }^{5}$ J. Pimlott, Wojna $w$ Wietnamie, Warszawa 1998, s. 14.

${ }^{6}$ A. Dмосноwsкi, op. cit., s. 43.

${ }^{7}$ Konferencja ta była nadzorowana przez międzynarodową komisję (według propozycji premiera Chińskiej Republiki Ludowej - Zhou Enlaia). W skład komisji wchodziły Polska, Kanada i Indie. Porozumienie podpisano w dniach 20-21 VII $1954 \mathrm{r}$. Wietnam został podzielony na dwie części wzdłuż 17 równoleżnika: północną - Demokratyczną Republikę Wietnamu oraz południową - Republikę Wietnamu, zaś Laos i Kambodża uzyskały niepodległość. W ciągu dwóch lat na terenie całego Wietnamu miały się odbyć wybory, w których ludność miała określić przyszły status zjednoczonego państwa.

8 J. Pimlott, op. cit., s. 27.

${ }^{9}$ Nazwa Vietcong jest skrótem frazy z języka wietnamskiego Việt Nam Cộng Sản, czyli „Wietnamski Komunista”. Początkowo określano tym terminem armię partyzancką o nazwie Ludowe Zbrojne Siły Wyzwoleńcze, a dopiero później członków Narodowego Frontu Wyzwolenia Wietnamu Południowego. 
ataku zginęło dwóch doradców wojskowych z Grupy Pomocy i Doradztwa Wojskowego (MAAG - Military Assistanse and Advisory Group) ${ }^{10}$ - mjr D. Buis i sierż. Ch. Ovnand, otwierając tym samym listę 58 tys. żołnierzy amerykańskich poległych w Wietnamie ${ }^{11}$.

Z taką sytuacją polityczną zmierzyć się musiał John F. Kennedy - kolejny prezydent Stanów Zjednoczonych ${ }^{12}$. Podobnie jak jego poprzednik, wierzył on głęboko w „teorię domina”, którą uznał za najważniejszy powód „amerykańskiej stawki w Wietnamie". Drugą przyczyną zaangażowania się USA w Wietnamie miał być według J.F. Kennedy’ego:

[...] doświadczony teren demokracji w Azji [...] alternatywa dla dyktatury komunistycznej. Jeśli to demokratyczne doświadczenie nie powiedzie się [...], to znaczenie demokracji w świadomości coraz większej liczby Azjatów będzie charakteryzować nie siła, lecz słabośćc ${ }^{13}$.

J.F. Kennedy uważał również, że skoro Wietnam jest próbą demokracji Azji, to jest on jednocześnie „próbą odpowiedzialności i determinacji” i gdyby Wietnam miał paść ofiarą komunizmu, to odpowiedzialność spadłaby na USA, a ich prestiż w Azji „spadłby jeszcze bardziej”" „jest bardzo egoistyczna”, ponieważ życie Amerykanów i amerykańskie dolary musiałyby być poświecone w przypadku zagrożenia dla obszaru kontrolowanego przez prezydenta Wietnamu Południowego, którym w tym czasie był Jean Baptiste Ngô Đình Diệm ${ }^{15}$.

Wychodząc z takich założeń, J.F. Kennedy w zasadzie dał do zrozumienia, że interwencja wojsk amerykańskich w Wietnamie jest przesądzona. Jedyną pozostałą niewiadomą był „oficjalny powód” i czas jej rozpoczęcia. Następca J.F. Keneddy’ego - Lyndon B. Johnson, pomimo różnych możliwości rozwiązania konfliktu, podjął kroki, które były stosunkowo łatwe do przewidzenia - mając na uwadze słowa, które wypowiedział w kilka dni po objęciu urzędu: „Nie mam zamiaru stracić Wietnamu. Nie będę tym prezydentem, który będzie się przyglądał, jak Azja Południowo-Wschodnia kroczy drogą, którą poszły Chiny”16. Mianował

${ }^{10}$ W początkowej fazie Grupa Pomocy i Doradztwa Wojskowego liczyła tylko 342 doradców. Liczba ta była uzgodniona na mocy porozumienia w Genewie w 1954 r. - P. Ostaszewski, op. cit., s. 334.

${ }^{11}$ Ibidem, s. 335.

12 J.F. Kennedy objął urząd 20 I 1961 r.

${ }^{13}$ N. Podhoretz, Dlaczego byliśmy w Wietnamie?, Gdynia-Warszawa 1991, s. 19.

${ }^{14}$ Ibidem, s. 20.

${ }^{15}$ Ibidem.

16 Ibidem, s. 97. 
również głównodowodzącym Dowództwa Pomocy Wojskowej (MACV - Military Assistance Command - Vietnam $)^{17}$ gen. Williama Westmorelanda, zwolennika interwencji USA w Wietnamie. Pretekstem do wojny stał się incydent na wodach Zatoki Tonkińskiej, który był częścią tajnej operacji ${ }^{18}$ rozpoczętej 17 lipca 1964 r. przez amerykański niszczyciel USS „Maddox”' ${ }^{19}$. W jej trakcie okręt (przebywający wówczas na wodach międzynarodowych) został zaatakowany przez północnowietnamskie kutry torpedowe ${ }^{20}$. Po tym incydencie, prezydent L. Johnson nakazał wysłanie noty protestacyjnej do Hanoi, w której przestrzegł przed poważnymi konsekwencjami, jakie mogą wyniknąć z dalszych niesprowokowanych ataków na amerykańskie jednostki przebywające na wodach międzynarodowych ${ }^{21}$. Dwa dni po wydaniu tej depeszy, ten sam niszczyciel został 4 sierpnia zaatakowany ponownie ${ }^{22}$. Tym razem, ten - tzw. drugi incydent w Zatoce Tonkińskiej, doprowadził do zaangażowania się USA w otwartą wojnę. Kongres zezwolił L. Johnsonowi, jako zwierzchnikowi sił zbrojnych, na: „[...] podjęcie wszelkich koniecznych kroków w celu odparcia jakichkolwiek zbrojnych ataków przeciwko siłom zbrojnym"23. W praktyce oznaczało to swobodę $\mathrm{w}$ podejmowaniu decyzji w sprawie wojny w Wietnamie.

17 Utworzone 8 II 1962 r. jako łącznik pomiędzy coraz liczniejszym kontyngentem doradców wojskowych USA a rządem południowokoreańskim. Z czasem dowódca MACV stal się głównodowodzącym wojsk amerykańskich w Wietnamie - J. PiмLotт, op. cit., s. 35.

${ }_{18}$ Od połowy lat pięćdziesiątych CIA prowadziła tajne operacje dywersyjne przeciwko północnemu Wietnamowi. Polegały one na nocnych rajdach zwerbowanych i przeszkolonych na Tajwanie południowowietnamskich komandosów przerzucanych łodziami rybackimi na terytorium Demokratycznej Republiki Wietnamu, gdzie niszczyli oni ważne gospodarczo i militarnie instalacje brzegowe. Ponieważ prędkość takich łodzi była bardzo mała, często zdarzało się, że stawały się one łupem północnowietnamskich okrętów patrolowych. Aby temu zaradzić, Amerykanie postanowili wyposażyć południowowietnamskie drużyny dywersyjne w bardzo szybkie kutry torpedowe klasy „Nasty”. Zrewidowany plan akcji dywersyjnej nazwano OPLAN 34A (Operation Plan 34) i pod nadzorem marynarki wojennej USA wdrożono w życie w 1963 r. Zmodyfikowany OPLAN 34A polegał również na zbieraniu wszelkich informacji na temat stanu armii i gospodarki północnowietnamskiej oraz zintensyfikowania wojny psychologicznej, dzięki czemu zamierzano ograniczyć kontrolę rządu w Hanoi nad społeczeństwem północnego Wietnamu. Dla ochrony całej akcji postanowiono użyć okrętów marynarki wojennej patrolujących wody przybrzeżne Demokratycznej Republiki Wietnamu - P. Ostaszewski, op. cit., s. 388.

19 Operacja nosiła kryptonim „De Soto” i miała na celu zlokalizowanie i zidentyfikowanie północnowietnamskich urządzeń radarowych, opisanie morskich szlaków handlowych, które mogły służyć do transportu broni na teren południowego Wietnamu, zebranie informacji na temat ruchu morskiego w Zatoce Tonkińskiej, dokładne sfotografowanie wszystkich celów - P. Ostaszewski, op. cit., s. 389.

${ }_{20}$ A. Dмосноwski, op. cit., s. 99.

${ }^{21}$ P. Ostaszewski, op. cit., s. 392.

${ }^{22}$ Co do tego drugiego incydentu trwa spór, czy rzeczywiście do niego doszło i czy nie była to ukartowana gra administracji prezydenta Johnsona.

${ }^{23}$ J. Pimlotт, op. cit., s. 38. 
Angażując się w konflikt na Półwyspie Indochińskim, dowództwo wojsk amerykańskich musiało w pierwszej kolejności zapewnić niezbędną infrastrukturę wojskową dla swoich oddziałów. Było to tym bardziej ważne zadanie, im bardziej wzrastała obecność wojsk amerykańskich w Wietnamie. Przed oficjalnym wybuchem konfliktu w 1964 r., obecność Amerykanów ograniczała się jedynie do tzw. doradców wojskowych, których nota bene liczba na początku lat sześćdziesiątych systematycznie rosła (liczbę żołnierzy amerykańskich zaangażowanych $\mathrm{w}$ konflikt $\mathrm{w}$ Wietnamie wraz z liczbą poległych, rannych i zaginionych w latach 1962-1972 przedstawia tabela 1). Przygotowanie wspomnianej infrastruktury wojskowej, a w szczególności budowa baz wojskowych, magazynów amunicji, składów paliwa, budowa lądowisk dla śmigłowców, baz dla odrzutowców itp. - spoczywała w większości na barkach wojsk inżynieryjnych.

Tabela 1

Liczba żołnierzy amerykańskich zaangażowanych w konflikt w Wietnamie wraz z liczbą poległych, rannych i zaginionych w latach 1962-1972

\begin{tabular}{|c|r|c|}
\hline Rok & Liczba żołnierzy & Liczba poległych w walce \\
\hline 1960 & 875 & \multirow{2}{*}{759} \\
\hline 1961 & 11326 & \\
\hline 1962 & 16263 & \\
\hline 1963 & 23310 & 137 \\
\hline 1964 & 184300 & 1369 \\
\hline 1965 & 385300 & 5008 \\
\hline 1966 & 485600 & 9378 \\
\hline 1967 & 536100 & 14592 \\
\hline 1968 & 475200 & 9414 \\
\hline 1969 & 334600 & 4221 \\
\hline 1970 & 156800 & 1380 \\
\hline 1971 & 24000 & 300 \\
\hline 1972 & & \\
\hline
\end{tabular}


Tabela 1 (cd.)

\begin{tabular}{|l|c|}
\hline & Liczba poległych w walce \\
\hline Liczba poległych w Wietnamie w trakcie walk & 46558 \\
\hline Liczba poległych w Wietnamie - nie w trakcie starć & 10390 \\
\hline Liczba rannych & ok. 300000 \\
\hline Liczba zaginionych w latach 1960-1972 & 2494 \\
\hline
\end{tabular}

Źró dło: J. Pıмเoтt, Wojna w Wietnamie, Warszawa 1998, s. 178.

Wojska inżynieryjne jako specyficzny rodzaj sił zbrojnych stały się niezbędnym komponentem poszczególnych związków taktycznych i gwarantem powodzenia działań militarnych prowadzonych przez armię amerykańską. Aby móc utrzymać ich odpowiednie tempo (np. poprzez zapewnienie odpowiedniej ilości mostów, przepraw, dróg, oczyszczonych pól minowych itp.), niezbędna była obecność dobrze wyposażonych wojsk inżynieryjnych.

Zanim jednak wojska amerykańskie i wspierające je odziały sojusznicze (australijskie, nowozelandzkie i południowowietnamskie) zaangażowały się na dużą skalę $\mathrm{w}$ działania bojowe, prace inżynieryjne na terenie Wietnamu wykonywane były w głównej mierze przez cywilnych kontrahentów. Świadczyli oni usługi na rzecz armii amerykańskiej już od końca lat pięćdziesiątych, kiedy to Amerykanie wspierali południowowietnamskie siły zbrojne tzw. personelem doradczym. Działalność cywilnych firm była w tym czasie ochraniana przez oddziały armii południowowietnamskiej (w szczególności przeciwko działaniom partyzanckich oddziałów Vietcongu). Jednym z największych cywilnych przedsiębiorstw działających wówczas w południowym Wietnamie było konsorcjum dwóch firm: Raymond International of Nowy Jork i Morrison-Knudsen of Asia, Inc. z siedzibą w Boise (w stanie Idaho), znane w skrócie jako $\mathrm{RMK}^{24}$. O tym, jak wielkie było to konsorcjum, świadczy liczba zatrudnianych pracowników, która w końcu 1962 r. wynosiła 3 tys. ludzi (z czego 2,9 tys. to Wietnamczycy) ${ }^{25}$. Początkowo umowa na świadczenie usług dla armii amerykańskiej była podpisana na 3 lata, ale wobec wybuchu w 1964 r. otwartego konfliktu - RMK pozostała na usługach armii do końca wojny. Jednym z największych zleconych jej projektów była rozbudowa bazy w Cam Ranh na południu Wietnamu i wybudowanie dużych lotnisk w Wietnamie dla amerykańskich sił powietrznych w Bien Hoa i Da Nang, rozbudowa bazy w Nha Trang, jak również budowa pasów startowych umożliwiających start

\footnotetext{
${ }^{24}$ A.G. Traas, Engineers at war. The United States Army in Vietnam, Washington 2010, s. 5.

${ }^{25}$ Ibidem, s. 6.
} 


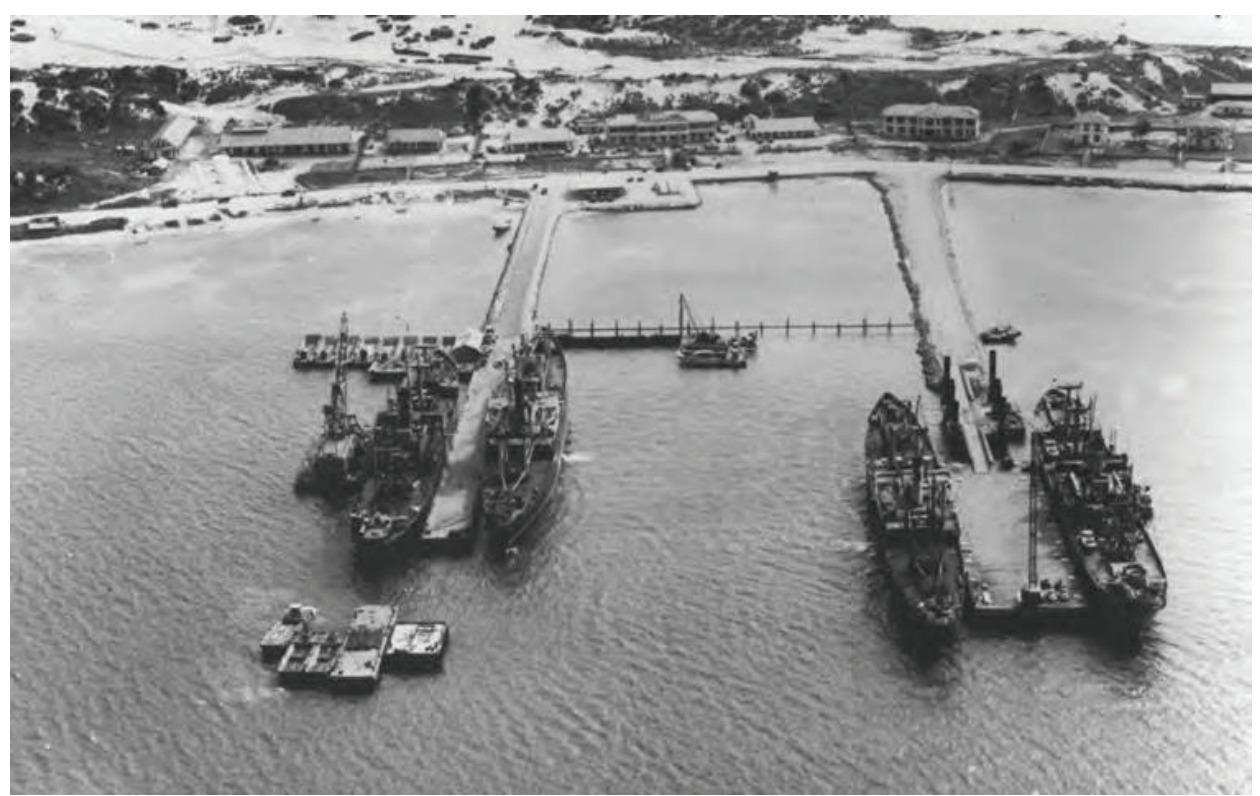

Fot. 1. Baza Cam Ranh z wybudowanym przez konsorcjum RMK sztucznym portem do cumowania okrętów transportowych, styczeń 1966.

Źró dło: A.G. TraAs, Engineers at war. The United States Army in Vietnam, Washington 2010, s. 29.

i lądowanie w każdych warunkach atmosferycznych w Can Tho oraz Pleiku. Za planowanie i zarządzanie rozbudową infrastruktury wojskowej w okresie tzw. „doradczym” odpowiadało Dowództwo Pomocy Wojskowej w Wietnamie (MACV - Military Assistance Command Vietnam) ${ }^{26}$.

W początkowym okresie konfliktu, tj. do 1 kwietnia 1965 r., wojska inżynieryjne w południowym Wietnamie składały się zaledwie $\mathrm{z}$ dwóch batalionów inżynieryjnych, jednej kompanii inżynieryjnej (przydzielonej do dowództwa wojsk amerykańskich), trzech samodzielnych kompanii inżynieryjnych oraz jednego samodzielnego plutonu. Łącznie było to niespełna tysiąc żołnierzy wojsk inżynieryjnych - na łączną liczbę 23 tys. żołnierzy amerykańskich znajdujących się w Wietnamie w grudniu $1964 \mathrm{r}^{27}$ Była to zdecydowanie za mała liczba w stosunku do zadań, jakie miały wykonywać wojska inżynieryjne. Rozbudowa infrastruktury wojskowej i przygotowanie jej dla stale napływających z USA żołnierzy wymagały znacznej rozbudowy sił inżynieryjnych. $\mathrm{Z}$ ich niewystarczających w stosunku do rosnących potrzeb sił - zdawał sobie doskonale sprawę ówczesny głównodowodzący wojsk amerykańskich w Wietnamie gen. W. Westmoreland,

\footnotetext{
${ }^{26}$ J. Pimlott, op. cit., s. 35.

27 A. Rawson, The Vietnam War - handbook, Gloucestershire 2008, s. 65.
} 
który wystąpił do przełożonych o przysłanie dodatkowych 2,4 tys. żołnierzy wojsk inżynieryjnych. Brak zrozumienia dla tej „prośby” - skutkował wysłaniem jedynie 80 żołnierzy tej formacji, choć szacuje się, że w tym okresie na terenie USA znajdowało się blisko 100 tys. rezerwistów wojsk inżynieryjnych ${ }^{28}$.

Ponawiane stale prośby gen. W. Westmorelanda o zwiększenie liczebności oddziałów inżynieryjnych zaczęły z upływem czasu odnosić skutek. W latach 1968-1969 wojska inżynieryjne liczyły już około 36-40 tys. żołnierzy, co stanowiło około $10 \%$ ogólnej liczby wojsk armii amerykańskiej stacjonujących w Wietnamie ${ }^{29}$. Spośród nich, 28 tys. żołnierzy wojsk inżynieryjnych podlegało bezpośrednio gen. D.S. Parkerowi, dowódcy wojsk inżynieryjnych w Wietnamie. Natomiast pozostałe 8 tys. zostało przydzielonych bezpośrednio do jednostek innych rodzajów broni i wojsk, w tym m.in. do czterech dywizji piechot, brygady powietrznodesantowej oraz brygady kawalerii pancernej. Trzon amerykańskich wojsk inżynieryjnych w Wietnamie stanowiła 18 i 20 Brygada Inżynieryjna. Obie jednostki przebywały w Wietnamie praktycznie w pełnym stanie etatowym i kompletnym wyposażeniem: 18 Brygada Inżynieryjna posiadała 95,5\% swojego stanu osobowego, zaś 20 Brygada Inżynieryjna - 99,1\% ${ }^{30}$ (vide schemat 1).

Obie wymienione brygady były podzielone na sześć tzw. grup inżynieryjnych (po trzy takie grupy w brygadzie), z których każda była odpowiedzialna za nadzorowanie prac wchodzących w ich skład 4-5 batalionów inżynieryjnych. Obszar, za który była odpowiedzialna dana grupa, odpowiadał granicom działania poszczególnych korpusów armii amerykańskiej. Przydział poszczególnych grup inżynieryjnych do utworzonych korpusów przedstawiał się następująco: I Korpus - 35 Grupa Inżynieryjna (w bazie Da Nang) oraz 45 Grupa Inżynieryjna (w bazie Phu Bai), ta ostatnia stacjonowała początkowo na obszarze II Korpusu w bazach Tuy Hoa oraz Qui Nhon; II Korpus Północ - 937 Grupa Inżynieryjna stacjonowała przy Qui Nhon przed przeniesieniem do Pleiku, a następnie w Phu Tai, zaś 45 Grupa Inżynieryjna stacjonowała w Tuy Hoa i Qui Nhon, przed przeniesieniem do I Korpusu; II Korpus Południe - 34 Grupa Inżynieryjna w bazie w Vung Tau (na początku konfliktu korpusowi podlegała także 35 Grupa Inżynieryjna w bazach w Phan Rang i Cam Ranh Bay); III Korpus - 159 Grupa Inżynieryjna w bazach Bien Hoa oraz w Long Binh i 79 Grupa Inżynieryjna w bazie Long Binh; IV Korpus - 34 Grupa Inżynieryjna w bazie Bin Thuy ${ }^{31}$.

Wchodzące w skład każdej z grup inżynieryjnych bataliony inżynieryjne dzieliły się na dwa rodzaje: bataliony inżynieryjne wsparcia oraz bataliony inżynieryjne budowlane. Różniły się one liczebnością, jak również posiadanym

\footnotetext{
${ }^{28}$ Ibidem.

29 A.G. TraAs, op. cit., s. 447.

${ }^{30}$ Ibidem, s. 448.

31 A. Rawson, op. cit., s. 66.
} 


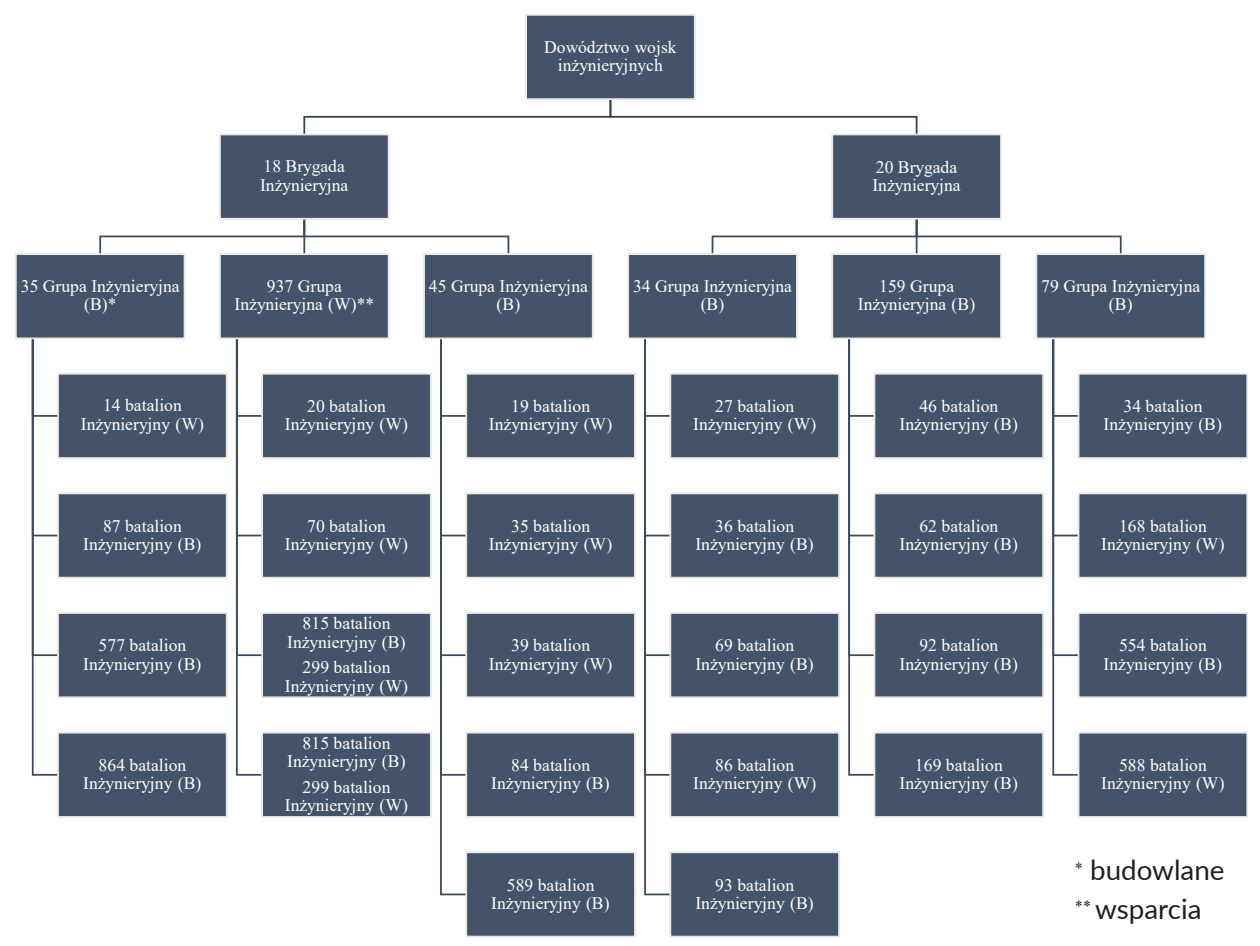

Schemat 1. Organizacja dowodzenia wojskami inżynieryjnymi w Wietnamie w listopadzie $1967 \mathrm{r}$. Źró dło: opracowanie własne na podstawie: A.G. TrAAs, Engineers at war. The United States Army in Vietnam, Washington 2010, s. 314.

wyposażeniem. Batalion wsparcia (tzw. większy) składał się z kompanii dowodzenia oraz 4 kompanii wsparcia (łącznie 39 oficerów i 755 żołnierzy), zaś na jego wyposażeniu znajdowało się m.in.: 10 buldożerów, 4 równiarki, 13 koparko-ładowarek, 3 dźwigi oraz 2 betoniarki. Co istotne - cały sprzęt mógł być przetransportowany przez ciężkie samoloty transportowe, a to z kolei czyniło $\mathrm{z}$ takiego batalionu oddział o wysokiej mobilności. Podobny jej poziom posiadał także batalion inżynieryjny wsparcia (tzw. mniejszy) składający się z kompanii dowodzenia oraz trzech kompanii wsparcia, mający etatowo 33 oficerów i 586 żołnierzy oraz m.in. 7 buldożerów, 3 równiarki i dwa dźwigi. Do głównych zadań batalionów wsparcia (obu typów) należało budowanie i wzmacnianie pozycji obronnych, oczyszczanie dróg, budowa mostów, niszczenie przeszkód, zakładanie i niszczenie pól minowych, a także wznoszenie budynków tworzących infrastrukturę wojskową ${ }^{32}$.

\footnotetext{
${ }^{32}$ Ibidem, s. 67.
} 


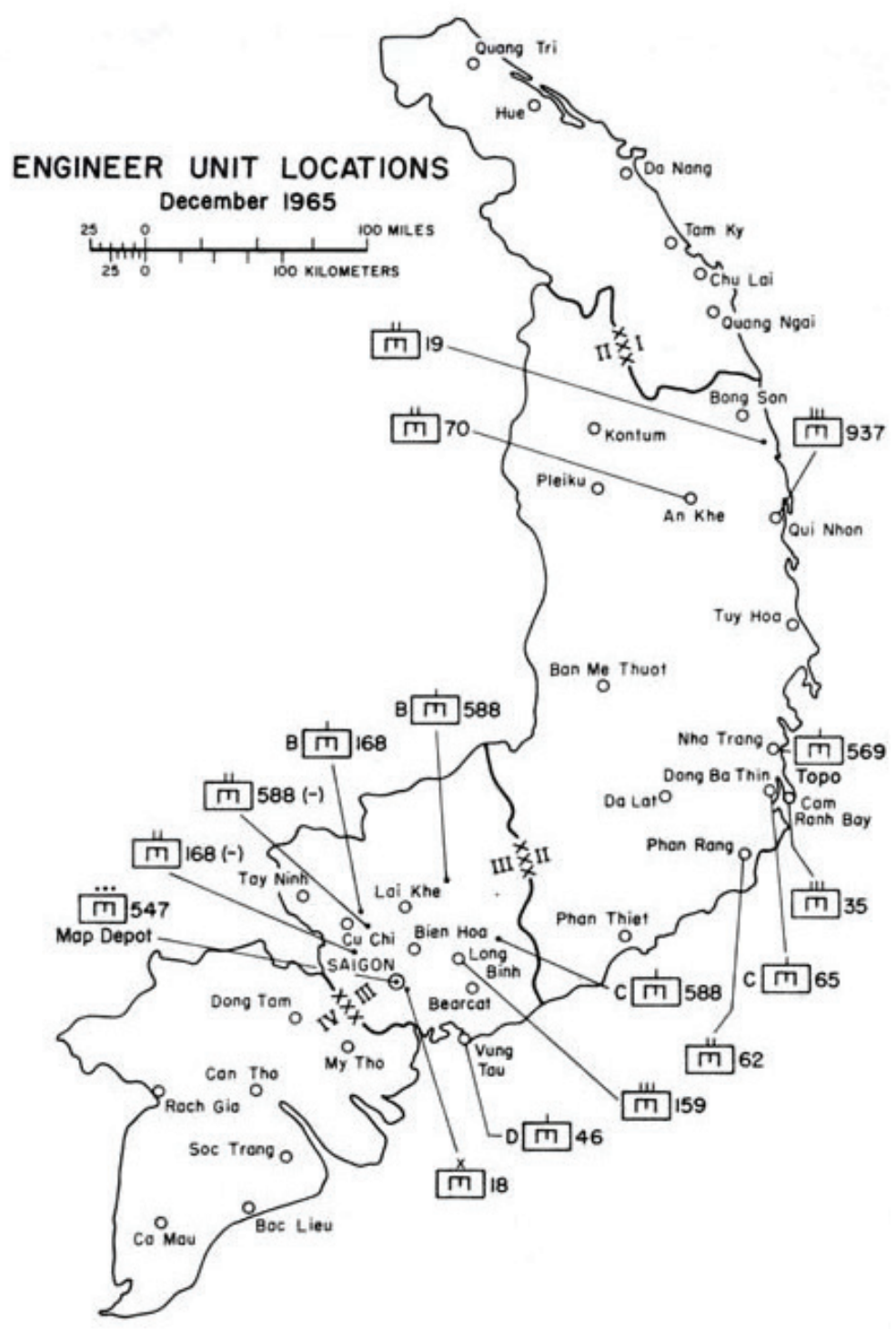

Mapa 1. Rozmieszczenie oddziałów wojsk inżynieryjnych w Wietnamie w grudniu $1965 \mathrm{r}$.

Źró d to: R. Ploger, Vietnam Studies: U.S. Army Engineers 1965-1970, Washington 2000, s. 82.

Z kolei bataliony inżynieryjne budowlane odpowiedzialne były w szczególności za rozbudowę i utrzymanie baz, lotnisk, lądowisk dla śmigłowców, instalacji dla potrzeb wojska (np. rurociągów), za utrzymanie linii komunikacyjnych na terenie Wietnamu (np. naprawa i budowa dróg, mostów), a także linii kolejowych 
i wodociągów. Batalion inżynieryjny budowlany składał się zazwyczaj z kompanii dowodzenia oraz trzech kompanii budowlanych, zaś jego stan etatowy wynosił 38 oficerów i 867 żołnierzy ${ }^{33}$.

Oprócz wymienionych batalionów wojsk inżynieryjnych, dowództwo wojsk amerykańskich w Wietnamie miało do swojej dyspozycji stosunkowo liczne wyspecjalizowane samodzielne kompanie inżynieryjne. Były to m.in. kompanie inżynieryjne zajmujące się budową konstrukcji portowych i morskich (posiadających w swoim składzie drużyny nurków), kompanie inżynieryjne (odpowiedzialne za pozyskiwanie i uzdatnianie wody), kompanie inżynieryjne kartograficzne (odpowiedzialne m.in. za wyznaczanie dróg przejazdu dla konwojów dostarczających amunicję), a także kompanie inżynieryjne topograficzne (odpowiedzialne m.in. za wyznaczanie „bezpiecznych” dróg w oparciu o zdjęcia lotnicze) - rozmieszczenie oddziałów inżynieryjnych na terenie Wietnamu w grudniu 1965 r. przedstawia mapa.

Ponadto, każda dywizja posiadała w swoich strukturach batalion inżynieryjny (tzw. dywizyjny batalion inżynieryjny), którego zadaniem było rozbudowywanie i utrzymanie baz, przygotowywanie lądowisk dla śmigłowców, naprawa i budowa dróg, mostów, jak również ochrona przeciwpożarowa bazy. Oprócz tego wydzielone pododdziały inżynieryjne zapewniały wsparcie w czasie operacji militarnych, prowadząc zadania torujące (np. niszczenie pól minowych, pułapek, tuneli lub zasieków) lub obronne dla swoich oddziałów (np. wznoszenie schronów, okopów, minowanie terenu itp.). Dywizyjny batalion inżynieryjny tworzyła kompania dowodzenia oraz trzy kompanie inżynieryjne (stan osobowy wynosił 46 oficerów i 901 żołnierzy) ${ }^{34}$.

Tabela 2

Wykaz dywizyjnych batalionów inżynieryjnych wchodzących w skład amerykańskich dywizji walczących w Wietnamie w latach 1964-1975

\begin{tabular}{|l|l|}
\hline \multicolumn{1}{|c|}{ Nazwa dywizji } & \multicolumn{1}{c|}{$\begin{array}{c}\text { Nazwa dywizyjnego batalionu } \\
\text { inżynieryjnego }\end{array}$} \\
\hline 1 Dywizja Kawalerii & 8 batalion inżynieryjny \\
\hline 1 Dywizja Piechoty & 1 batalion inżynieryjny \\
\hline 4 Dywizja Piechoty & 4 batalion inżynieryjny \\
\hline
\end{tabular}

\footnotetext{
33 Ibidem.

${ }^{34}$ Ibidem, s. 70.
} 
Tabela 2 (cd.)

\begin{tabular}{|l|l|}
\hline \multicolumn{1}{|c|}{ Nazwa dywizji } & \multicolumn{1}{c|}{$\begin{array}{c}\text { Nazwa dywizyjnego batalionu } \\
\text { inżynieryjnego }\end{array}$} \\
\hline 9 Dywizja Piechoty & 15 batalion inżynieryjny \\
\hline 23 Dywizja Piechoty & 26 batalion inżynieryjny \\
\hline 25 Dywizja Piechoty & 65 batalion inżynieryjny \\
\hline 101 Dywizja Powietrznodesantowa & 326 batalion inżynieryjny \\
\hline 1 Dywizja Piechoty Morskiej & 1 batalion inżynieryjny piechoty morskiej \\
\hline 3 Dywizja Piechoty Morskiej & 3 batalion inżynieryjny piechoty morskiej \\
\hline
\end{tabular}

Źró dło: opracowanie własne na podstawie: A. RAwson, The Vietnam War - handbook, Gloucestershire 2008, s. 71.

Wysiłek oddziałów inżynieryjnych w czasie trwającego w latach 1964-1975 konfliktu wietnamskiego był ogromny. Bez ich pracy i poświęcenia funkcjonowanie jednostek armii amerykańskiej oraz planowanie operacji wojskowych byłoby bardzo trudne, a wręcz nawet niemożliwe. Pracując w ekstremalnie trudnych warunkach klimatycznych, żołnierze wojsk inżynieryjnych potwierdzili swoją wartość, a zarazem niezbędność, zarówno na polu walki, jak i poza nim. Z uwagi na tropikalny klimat Wietnamu, wiele prac wykonywanych przez oddziały inżynieryjne odbywało się w nocy, co z kolei zmuszało ich żołnierzy do odpoczynku i snu w najgorętszych częściach dnia. Z racji częstego przemieszczania się i specyfiki wykonywanych prac, najczęstszym miejscem zakwaterowania żołnierzy tych formacji były namioty lub ziemianki. Najbardziej dokuczliwy z racji warunków klimatycznych stawał się nierzadko brak odpowiedniej ilości wody pitnej. Kluczowym zadaniem zapewniającym mobilność dla swoich wojsk było naprawianie, budowanie i utrzymywanie sieci dróg lokalnych. Jak wielki był to wysiłek budowlany oddziałów inżynieryjnych świadczy fakt, że od 1968 do 1970 r. wybudowały one $2300 \mathrm{~km}$ nowych dróg (średnie tempo budowania nowej drogi wynosiło $5,5 \mathrm{~km}$ na tydzień) ${ }^{35}$. Wybudowanie takiej długości dróg nie mogło się odbyć bez pozyskiwania z kamieniołomów ogromnych ilości kruszywa, z czym był zazwyczaj problem. W tym celu w latach 1968-1970 żołnierze oddziałów inżynieryjnych pozyskiwali 150 tys. ton ${ }^{36}$. Pomimo ciągłego zagrożenia ze strony partyzantki północnowietnamskiej, żołnierze pracowali nieprzerwanie $z$ wielkim poświęceniem.

\footnotetext{
35 Ibidem, s. 69.

36 Ibidem.
} 
Ogromnym wyzwaniem okazało się także utrzymanie i odbudowywanie często uszkadzanej przez Vietcong południowowietnamskich linii kolejowych. Dzięki wysiłkowi oddziałów inżynieryjnych w latach 1967-1971, wspomniane koleje przewiozły ponad 2 miliony pasażerów Wietnamu Południowego ${ }^{37}$.

W czasie trwającego 11 lat konfliktu, w oddziałach wojsk inżynieryjnych służbę swoją pełniło w systemie rotacyjnym łącznie 200 tys. żołnierzy, spośród których w trakcie działań wojennych 1,5 tys. poniosło śmierć (w tym 143 oficerów) ${ }^{38}$.

\author{
Robert Pietrygała, Zdzisław Cutter
}

\title{
AMERICAN ENGINEERING TROOPS IN THE VIETNAM CONFLICT OF 1964-1975
}

\begin{abstract}
Summary: The article focuses on the period of the Vietnam War, with particular emphasis on the role played by engineering troops (as a necessary component of individual tactical associations, and a guarantee of success of military operations conducted by the US army). The paper presents the engineering troops' efforts to build military infrastructure, as well as the assistance provided to the South Vietnamese society. The article contains a list of all engineering units of the American army involved in the Vietnamese conflict, their organizational structure, personnel status, dislocation, as well as the scope of tasks assigned to them. In addition, it shows the cooperation between engineering units and civil contractors at the service of the army (especially in the period preceding the direct involvement of the United States in the war).
\end{abstract}

Keywords: the Vietnam War, American engineering troops, organizational structure, dislocation, civil contactors.

${ }^{37}$ Ibidem.

38 A.G. TraAs, op. cit., s. 579. 